DOI: $10.6060 / \mathrm{mhc} 201128 \mathrm{~d}$

\title{
Interaction of Cob(III)alamins with Hypothiocyanite. Evidence for the Formation of Hypothiocyanitocobalamin
}

\author{
Ilia A. Dereven'kov, ${ }^{\circledR}$ and Vladimir S. Osokin \\ Ivanovo State University of Chemistry and Technology, 153000 Ivanovo, Russia \\ ${ }^{\circledR}$ Corresponding authorE-mail: derevenkov@gmail.com
}

\begin{abstract}
Here, we report the results of investigation of the reactions between cobalamins (Cbls) and hypothiocyanite (OSCN $)^{-}$, a product of thiocyanate oxidation by hydrogen peroxide in the presence of lactoperoxidase. In the case of aquacobalamin, the product, the UV-vis spectrum of which differs from the UV-vis spectra of Cbl(III)-complexes with $\mathrm{SCN}^{-}, \mathrm{SO}_{3}^{2-}, \mathrm{OCN}^{-}$ and $C N^{-}$anions, is formed and attributed to hypothiocyanitocobalamin. This complex reacts with selenomethionine at substantially lower rate than the free $\mathrm{OSCN}^{-}$. Cyano- and methyl-Cbls are relatively stable in the presence of $\mathrm{OSCN}^{-}$. Glutathionylcobalamin is transformed to hypothiocyanitocobalamin in the presence of OSCN- excess via the oxidation of glutathionyl-ligand and subsequent binding of $O S C N^{-}$by Cbl(III).
\end{abstract}

Keywords: Cobalamins, hypothiocyanite, lactoperoxidase, thiocyanate, coordination.

\section{Взаимодействие Со(III)-форм кобаламинов с гипотиоцианитом. ПодтвержАение образования гипотиоцианитокобаламина}

\author{
И. А. Аеревеньков, ${ }^{\circledR}$ В. С. Осокин \\ Ивановский государственньій химико-технологический университет, 153000 Иваново, Россия \\ @E-mail:derevenkov@gmail.com
}

\begin{abstract}
Представлень результать исследования реакций кобаламинов (Cbls) и гипотиоцианитом (OSCN $\left.{ }^{-}\right)$, образуюшимся в результате окисления тиоцианата пероксидом водорода в присутствии лактопероксидазы. При взаимодействии аквакобаламина с OSCN образуется продукт, который имел электронный спектр поглощения (ЭСП), отличающийся от ЭСП комплексов $\mathrm{Cbl(III)} \mathrm{c} \mathrm{SCN}{ }^{-}, \mathrm{OCN}^{-}, \mathrm{SO}_{3}^{2-}$ и $\mathrm{CN}^{-}$, и был отнесен к гипотиочианитокобаламину. Этот комплекс реагирует с селенометионином значительно медленнее, чем свободный гипотиоцианит. Показано, что цииано- и метилкобаламинь устойчивы в присутствии OSCN. Глутатионилкобаламин переходит в гипотиочииантокобаламин в присутствии избытка OSCN $N^{-}$через окисление глутатионильного лиганда и последующее связывание $\mathrm{OSCN}^{-}$Co(III)-кобаламином.
\end{abstract}

Ключевые слова: Кобаламины, гипотиоцианит, лактопероксидаза, тиоцианат, координация.

Hypothiocyanite $\left(\mathrm{OSCN}^{-}\right)$is the product of thiocyanate $\left(\mathrm{SCN}^{-}\right)$oxidation by hydrogen peroxide mediated by peroxidases (i.e., lacto-, myelo- and eosinophile peroxidases). ${ }^{[1]}$ Reactions between $\mathrm{SCN}^{-}$with several other oxidants (i.e., hypochlorite, ${ }^{[2 \mathrm{a}]}$ hypobromite, ${ }^{\left[{ }^{[\mathrm{b}]}\right.}$ chloramine, ${ }^{[2 \mathrm{c}]}$ peroxomonosulfate ${ }^{[2 \mathrm{~d}]}$ ) lead to $\mathrm{OSCN}^{-}$as well. $\mathrm{OSCN}^{-}$ is an important component of immune system damaging the pathogen cells. ${ }^{[3]}$ However, several negative effects on human health are associated with $\mathrm{OSCN}^{-} .{ }^{[4]}$ In contrast to the other products generated by above-mentioned peroxidases (viz., hypochlorite and hypobromite), it is a relatively soft oxidant predominantly reacting with thiol groups. ${ }^{[5]}$ Reactions of $\mathrm{OSCN}^{-}$with selenium species (e.g., selenols and selenomethionine), ${ }^{[6]}$ tryptophane, ${ }^{[7]}$ and other substrates have been reported as well. Several works analyze the stability of $\mathrm{OSCN}^{-} \cdot{ }^{[8]}$ However, there is a little attention paid to the coordination properties of $\mathrm{OSCN}^{-}$. Only transient formation of $\mathrm{OSCN}^{-}$bound to ruthenium(III) ion 
was suggested in the course of $\mathrm{SCN}^{-}$oxidation by $\mathrm{H}_{2} \mathrm{O}_{2}$ or peroxomonosulfate in the presence of $\mathrm{Ru}$ (III)(edta) complex. ${ }^{[9]}$

Cobalamins (Cbls) are the ubiquitous cobalt corrin complexes. ${ }^{[10]} \mathrm{Cbls}$ are cofactors for methionine synthase and methylmalonyl-CoA mutase. ${ }^{[11]}$ Behavior of Cbls in the catalysis ${ }^{[12]}$ and medicine ${ }^{[13]}$ has been thoroughly highlighted as well. Co(III)-ion in aquacobalamin $\left(\mathrm{H}_{2} \mathrm{OCbl}\right)$ is capable of binding various anionic and neutral ligands. ${ }^{[14]}$ For example, Cbl(III) forms a tight complex with $\mathrm{CN}^{-}\left(K=1 \cdot 10^{12} \mathrm{M}^{-1}\right)^{[15]}$ and much weaker complexes with $\mathrm{SCN}^{-}\left(K=1.1 \cdot 10^{3} \mathrm{M}^{-1} \text { at } 25.0^{\circ} \mathrm{C}, I=2.2 \mathrm{M}\right)^{[16]}$ and $\mathrm{OCN}^{-}$ $\left(K=3.7 \cdot 10^{2} \mathrm{M}^{-1}\right.$ at $\left.25.0{ }^{\circ} \mathrm{C}, I=2.2 \mathrm{M}\right) .{ }^{[16 a]}$ In this work, we have examined complexation of $\mathrm{OSCN}^{-}$with $\mathrm{H}_{2} \mathrm{OCbl}$ in weakly acidic medium.

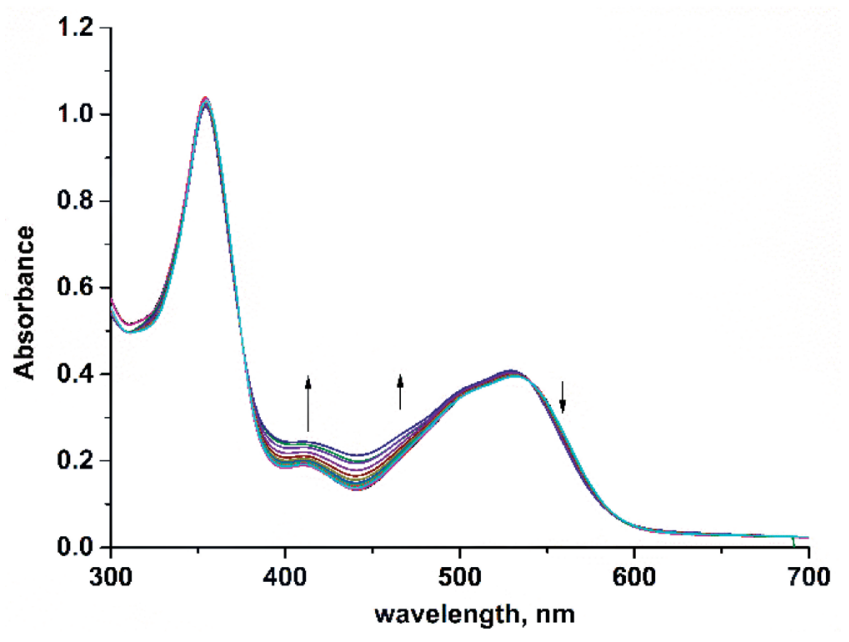

Figure 1. UV-vis spectra collected after mixing of $\mathrm{H}_{2} \mathrm{OCbl}$ $\left(5.0 \cdot 10^{-5} \mathrm{M}\right)$ with $\mathrm{LPO}(c a .0 .6 \mathrm{U} / \mathrm{mL}), \mathrm{SCN}^{-}(2.0 \mathrm{mM})$ and $\mathrm{H}_{2} \mathrm{O}_{2}$ $(2.0 \mathrm{mM})$ at $\mathrm{pH} 6.5$ and $25.0^{\circ} \mathrm{C}$. Mixture of LPO (ca. $\left.0.6 \mathrm{U} / \mathrm{mL}\right)$, $\mathrm{SCN}^{-}(2.0 \mathrm{mM})$ and $\mathrm{H}_{2} \mathrm{O}_{2}(2.0 \mathrm{mM})$ at $\mathrm{pH} 6.5$ generates $\left[\mathrm{OSCN}^{-}\right]=1.0 \mathrm{mM}$. Time interval between spectra is $1 \mathrm{~min}$. The initial spectrum corresponds to thiocyanatocobalamin, the final spectrum - to new Cbl(III) complex.

The addition of $\mathrm{H}_{2} \mathrm{OCbl}$ to the mixture of lactoperoxidase (LPO), $\mathrm{SCN}^{-}$and $\mathrm{H}_{2} \mathrm{O}_{2}$ results in rapid formation of thiocyanatocobalamin and further slower reaction illustrated by UV-vis spectral changes (Figure 1), i.e. an increase in absorbance is observed between $375-540 \mathrm{~nm}$. These observations cannot be explained by the absorbance of free $\mathrm{OSCN}^{-}$, which exhibits very weak peak at $376 \mathrm{~nm}$ (extinction coefficient is $26.5 \mathrm{M}^{-1} \cdot \mathrm{cm}^{-1}$ ) and negligibly absorbs at $410-540 \mathrm{~nm}$ (Figure S1 of Supporting Information). ${ }^{[17]}$ The products of $\mathrm{OSCN}^{-}$decomposition (viz., $\mathrm{OCN}^{-}, \mathrm{SO}_{3}^{2-}$ and $\left.\mathrm{CN}^{-}\right)^{[8 c, 17]}$ are capable of binding to $\mathrm{Cbl}(\mathrm{III})$, however, their UV-vis spectra (Figure 2) do not support formation of cyano-, sulfito- and cyanatocobalamins in the $\mathrm{H}_{2} \mathrm{OCbl} /$ $\mathrm{LPO} / \mathrm{SCN}^{-} / \mathrm{H}_{2} \mathrm{O}_{2}$ system. Similar UV-vis spectral changes were obtained upon mixing of $\mathrm{H}_{2} \mathrm{OCbl}$ with $\mathrm{OSCN}^{-} / \mathrm{SCN}^{-}$ mixture prepared via basic hydrolysis of thiocyanogen $\left((\mathrm{SCN})_{2}\right.$; Figure S2). ${ }^{[8 a, 17]} \mathrm{UV}$-vis spectral changes illustrated in Figure 1 are different from those observed for $\mathrm{H}_{2} \mathrm{OCbl} /$ $\mathrm{LPO} / \mathrm{H}_{2} \mathrm{O}_{2}$ system in the absence of $\mathrm{SCN}^{-}$(Figure $\mathrm{S} 3$ ): even in the presence of high LPO quantities, slow $\mathrm{H}_{2} \mathrm{OCbl}$ degradation is observed. Thus, we attribute the spectra shown in Figure 1 to the formation of hypothiocyanitocobalamin.

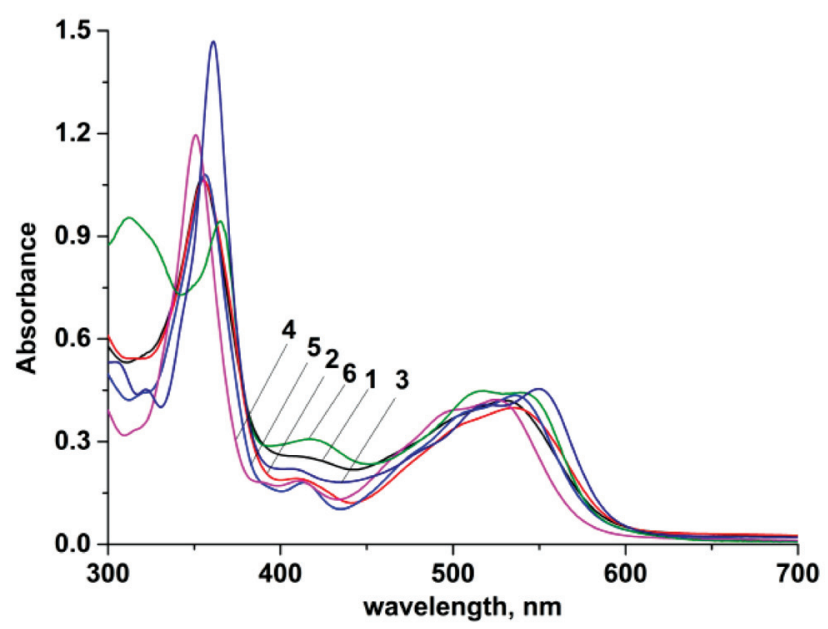

Figure 2. UV-vis spectra of the product of the reaction between $\mathrm{H}_{2} \mathrm{OCbl}$ and the mixture of LPO $(c a .0 .6 \mathrm{U} / \mathrm{mL}), \mathrm{SCN}^{-}(5.0 \mathrm{mM})$ and $\mathrm{H}_{2} \mathrm{O}_{2}(1.0 \mathrm{mM} ; 1)$, thiocyanatocobalamin (2), cyanocobalamin (3), $\mathrm{H}_{2} \mathrm{OCbl}$ (4), cyanatocobalamin (5) and sulfitocobalamin (6). $[\mathrm{Cbls}]=5 \cdot 10^{-5} \mathrm{M} ; \mathrm{pH} 6.5 ; 25.0^{\circ} \mathrm{C}$. Mixture of LPO (ca. $0.6 \mathrm{U} / \mathrm{mL}), \mathrm{SCN}^{-}(5.0 \mathrm{mM})$ and $\mathrm{H}_{2} \mathrm{O}_{2}(1.0 \mathrm{mM})$ at $\mathrm{pH} 6.5$ generates $\left[\mathrm{OSCN}^{-}\right]=0.9 \mathrm{mM}$.

Next, behavior of the other $\mathrm{Cbl}$ species in $\mathrm{LPO} / \mathrm{SCN}^{-} /$ $\mathrm{H}_{2} \mathrm{O}_{2}$ system was examined. Cyano- $(\mathrm{CNCbl})$ and methylcobalamins $(\mathrm{MeCbl})$, which contain tightly bound ligands in the upper axial position, do not react with species derived from $\mathrm{LPO} / \mathrm{SCN}^{-} / \mathrm{H}_{2} \mathrm{O}_{2}$ system (Figures $\mathrm{S} 4$ and S5). Glutathionylcobalamin (GSCbl), another tight $\mathrm{Cbl}(\mathrm{III})$-complex, undergoes transformation in $\mathrm{LPO} / \mathrm{SCN}^{-} / \mathrm{H}_{2} \mathrm{O}_{2}$ system to hypothiocyanitocobalamin (Figure S6), probably, via oxidation of glutathione motif by $\mathrm{OSCN}^{-}$, since thiol group is highly reactive toward $\mathrm{OSCN}^{-}{ }^{-[5]}$ However, substitution of glutathionyl-ligand by $\mathrm{OSCN}^{-}$with subsequent oxidation of free glutathione (GSH) by $\mathrm{OSCN}^{-}$cannot be excluded as well.

To determine equilibrium constant for hypothiocyanitocobalamin formation $\left(K_{1}\right)$, titration of thiocyanatocobalamin by $\mathrm{OSCN}^{-}$in the presence of constant $\mathrm{SCN}^{-}$concentration $(0.01 \mathrm{M})$ was performed (Figure S7). Using eq. (S2), $K_{1}=(1.1 \pm 0.2) \cdot 10^{4} \mathrm{M}^{-1}\left(\mathrm{pH} 6.5 ; 25.0{ }^{\circ} \mathrm{C}\right)$ was calculated. This value is $c a$. 10 -fold higher than equilibrium constant for thiocyanatocobalamin formation. ${ }^{[16 a]}$ Hypothiocyanitocobalamin is relatively unstable and undergoes decomposition to thiocyanatocobalamin (Figure 3) with the rate constant $k=(1.2 \pm 0.1) \cdot 10^{-3} \mathrm{~s}^{-1}\left(\mathrm{pH} 6.3 ; 25.0{ }^{\circ} \mathrm{C} ;\left[\mathrm{SCN}^{-}\right]=10.0 \mathrm{mM}\right)$.

$\mathrm{OSCN}^{-}$is reactive toward selenomethionine (Sem) with a rate constant of $2.8 \cdot 10^{3} \mathrm{M}^{-1} \cdot \mathrm{s}^{-1}\left(\mathrm{pH} 7.4 ; 25.0^{\circ} \mathrm{C}\right) .{ }^{[6]} \mathrm{We}$ examined how $\mathrm{OSCN}^{-}$binding to $\mathrm{Cbl}(\mathrm{III})$ affects its oxidizing properties using Sem as poorly coordinating ligand to Cbl(III) (i.e., Sem does not bind Cbl(III) in applied concentration range; Figure S8). Reaction of hypothiocyanitocobalamin with Sem conducted under the excess of $\mathrm{SCN}^{-}$produces thiocyanatocobalamin and is characterized by the first 


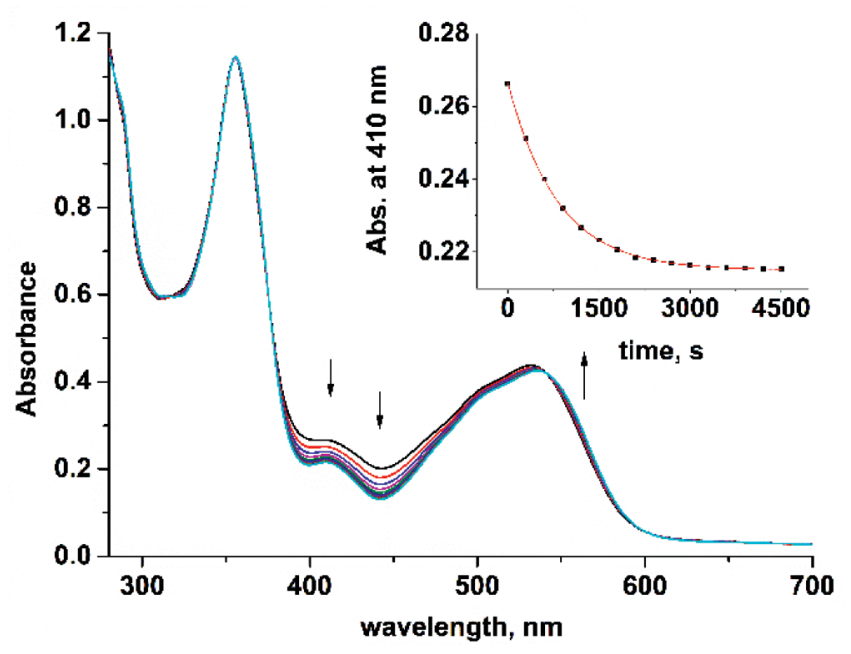

Figure 3. UV-vis spectra collected during decomposition of hypothiocyanitocobalamin $\left(5.0 \cdot 10^{-5} \mathrm{M}\right)$ at $\mathrm{pH} 6.3,25.0^{\circ} \mathrm{C}$, $\left[\mathrm{OSCN}^{-}\right]_{0}=0.8 \mathrm{mM}$. Insert: kinetic curve of the reaction. is transformed to hypothiocyanitocobalamin, probably, via oxidation of glutathionyl-ligand by $\mathrm{OSCN}^{-}$.

Acknowledgements. This work was supported by the Russian Science Foundation (Project No. 19-73-00147) to IAD.

\section{References}

1. a) Nagy P., Alguindigue S.S., Ashby M.T. Biochemistry 2006, 45, 12610-12616 (doi: 10.1021/bi061015y); b) Furtmüller P.G., Jantschko W., Regelsberger G., Jakopitsch G., Arnhold J., Obinger C. Biochemistry 2002, 41, 11895-11900 (doi: 10.1021/ bi026326x); c) van Dalen C.J., Whitehouse M.W., Winterbourn C.C., Kettle A.J. Biochem. J. 1997, 327, 487-492 (doi: 10.1042/ bj3270487); d) Slungaard A., Mahoney J.R. J. Biol. Chem. 1991, 266, 4903-4910; e) Schlorke D., Flemmig J., Gaua J., Furtmüller P.G., Obinger C., Arnhold J. J. Inorg. Biochem. 2016, 162, 117-126 (doi: 10.1016/j.jinorgbio.2016.06.019).

2. a) Ashby M.T., Carlson A.C., Scott M.J. J. Am. Chem. Soc. 2004, 126, 15976-15977 (doi: 10.1021/ja0438361); b) Nagy
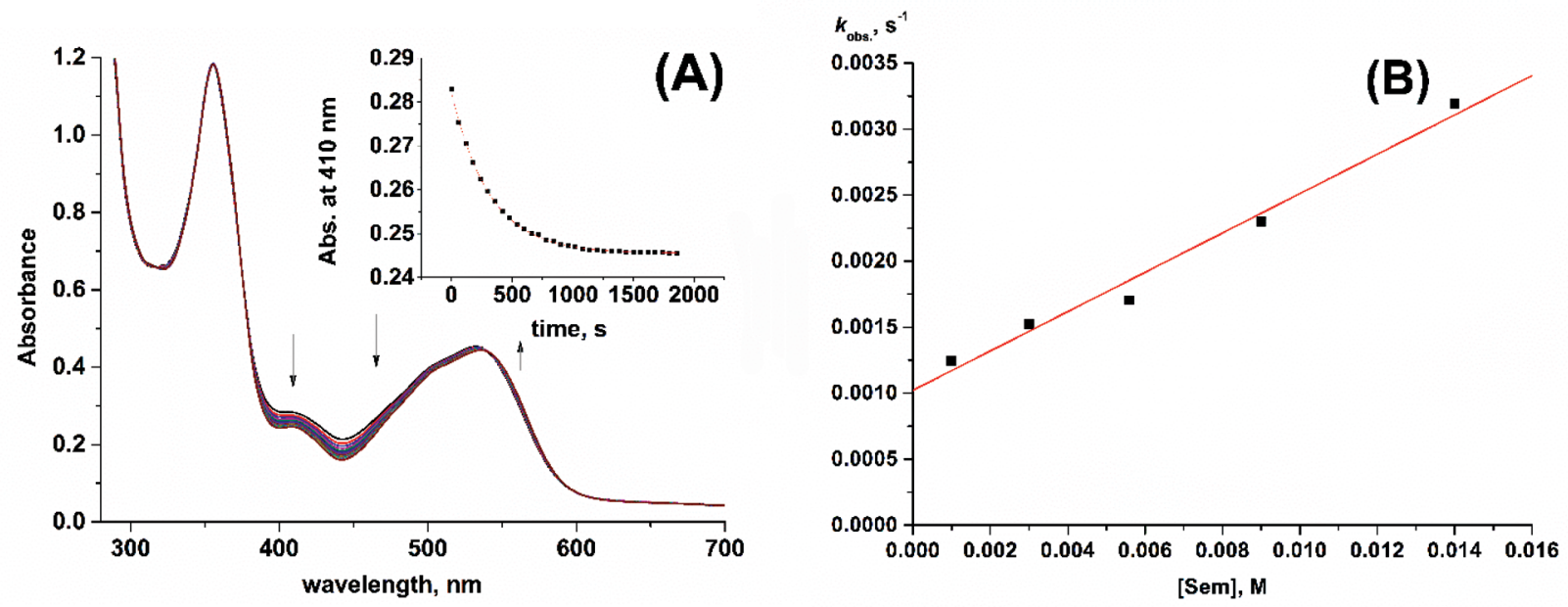

Figure 4. UV-vis spectra of the reaction between hypothiocyanitocobalamin $\left(5.0 \cdot 10^{-5} \mathrm{M}\right)$ and selenomethionine $\left(\mathrm{Sem} ; 1.4 \cdot 10^{-2} \mathrm{M} ; \mathrm{A}\right)$ and the plot of observed rate constant $\left(k_{\text {obs. }}\right)$ versus $[\mathrm{Sem}](\mathrm{B})$ at $\mathrm{pH} 6.3,25.0^{\circ} \mathrm{C},\left[\mathrm{OSCN}^{-}\right]_{0}=0.8 \mathrm{mM},\left[\mathrm{SCN}^{-}\right]=10.0 \mathrm{mM}$. Insert: kinetic curve of the reaction between hypothiocyanitocobalamin $\left(5.0 \cdot 10^{-5} \mathrm{M}\right)$ and $\operatorname{Sem}\left(1.4 \cdot 10^{-2} \mathrm{M}\right)$.

order with respect to hypothiocyanitocobalamin (Figure 4). The dependence of the observed rate constant on [Sem] exhibits the positive intercept, which value coincides with a rate constant of hypothiocyanitocobalamin decomposition under given conditions (vide supra). The value of the slope is $(1.5 \pm 0.2) \cdot 10^{-1} \mathrm{M}^{-1} \cdot \mathrm{s}^{-1}$, which is substantially lower than the rate constants for the reactions of free $\mathrm{OSCN}^{-}$with Sem. Thus, binding to $\mathrm{Cbl}(\mathrm{III})$ substantially decreases the reactivity of $\mathrm{OSCN}^{-}$.

In this work, we provided an evidence for the formation of the complex between $\mathrm{Cbl}(\mathrm{III})$ and the product generated in $\mathrm{LPO} / \mathrm{SCN}^{-} / \mathrm{H}_{2} \mathrm{O}_{2}$ system, the UV-vis spectrum of which differs from that of $\mathrm{Cbl}(\mathrm{III})$-complexes with $\mathrm{SCN}^{-}$, $\mathrm{OCN}^{-}$or $\mathrm{CN}^{-}$. This product was attributed to hypothiocyanitocobalamin. It exhibits oxidizing properties toward Sem, although it is substantially less reactive than free $\mathrm{OSCN}^{-}$. $\mathrm{CNCbl}$ and $\mathrm{MeCbl}$ are inert toward $\mathrm{OSCN}^{-}$, whereas $\mathrm{GSCbl}$
P., Beal J.L., Ashby M.T. Chem. Res. Toxicol. 2006, 19, 587-593 (doi: 10.1021/tx050338c); c) Xulu B.A., Ashby M.T. Biochemistry 2010, 49, 2068-2074 (doi: 10.1021/bi902089w); d) Kalmár J., Lente G., Fábián I. Inorg. Chem. 2013, 52, 2150-2156 (doi: 10.1021/ic302544y).

3. Hawkins C.L. Free Radic. Res. 2009, 43, 1147-1158 (doi: 10.3109/10715760903214462).

4. Barrett T.J., Hawkins C.L. Chem. Res. Toxicol. 2012, 25, 263-273 (doi: 10.1021/tx200219s).

5. a) Barrett T.J., Pattison D.I., Leonard S.E., Carroll K.S., Davies M.J., Hawkins C.L. Free Radic. Biol. Med. 2012, 52, 1075-1085 (doi: 10.1016/j.freeradbiomed.2011.12.024); b) Skaff O., Pattison D.I., Davies M.J. Biochem. J. 2009, 422, 111-117 (doi: 10.1042/BJ20090276); c) Nagy P., Jameson G.N., Winterbourn C.C. Chem. Res. Toxicol. 2009, 22, 1833-1840 (doi: 10.1021/tx900249d).

6. Skaff O., Pattison D.I., Morgan P.E., Bachana R., Jain V.K., Priyadarsini K.I., Davies M.J. Biochem. J. 2012, 441, 305-316 (doi: 10.1042/BJ20101762). 
7. Hawkins C.L., Pattison D.I., Stanley N.R., Davies M.J. Biochem. J. 2008, 416, 441-452 (doi: 10.1042/BJ20070941).

8. a) Nagy P., Wang X., Lemma K., Ashby M.T. J. Am. Chem. Soc. 2007, 129, 15756-15757 (doi: 10.1021/ja0770532); b) Nagy P., Lemma K., Ashby M.T. Inorg. Chem. 2007, 46, 285-292 (doi: 10.1021/ic061470i); c) Kalmár J., Woldegiorgis K.L., Biri B., Ashby M.T. J. Am. Chem. Soc. 2011, 133, 19911-19921 (doi: 10.1021/ja2083152).

9. a) Chatterjee D., Paul B., Mukherjee R. Dalton Trans. 2013, 42, 10056-10060 (doi: 10.1039/c3dt50723h); b) Sarkar P., Chatterjee D. Int. J. Chem. Kin. 2016, 48, 117-123 (doi: 10.1002/kin.20976).

10. a) Brown K.L. Chem. Rev. 2005, 105, 2075-2149 (doi: 10.1021/ cr030720z); b) Dereven'kov I.A., Salnikov D.S., SilaghiDumitrescu R., Makarov S.V., Koifman O.I. Coord. Chem. Rev. 2016, 309, 68-83 (doi: 10.1016/j.ccr.2015.11.001).

11. Kräutler B. Biochem. Soc. Trans. 2005, 33, 806-810 (doi: 10.1042/BST0330806).
12. Giedyk M., Goliszewska K., Gryko D. Chem. Soc. Rev. 2015, 44, 3391-3404 (doi: 10.1039/C5CS00165J).

13. Zelder F. Chem. Commun. 2015, 51, 14004-14017 (doi: 10.1039/C5CC04843E).

14. Marques H.M., Knapton L. J. Chem. Soc., Dalton Trans. 1997, 3827-3833 (doi: 10.1039/A703139D).

15. Hayward G.C., Hill H.A.O., Pratt J.M., Vanston N.J., Williams R.J.O. J. Chem. Soc. 1965, 6485-6493 (doi: 10.1039/ JR9650006485).

16. a) Knapton L., Marques H.M. Dalton Trans. 2005, 889-895 (doi: 10.1039/B416083E); b) Garau G., Geremia S., Marzilli L.G., Nardin G., Randaccio L., Tauzher G. Acta Cryst. 2003, B59, 51-59 (doi: 10.1107/S0108768102019353); c) Dereven'kov I.A., Salnikov D.S., Makarov S.V., Surducan M., Silaghi-Dumitrescu R., Boss G.R. J. Inorg. Biochem. 2013, 125, 32-39 (doi: 10.1016/j.jinorgbio.2013.04.011).

17. Ashby M.T. Adv. Inorg. Chem. 2012, 64, 263-303 (doi: 10.1016/B978-0-12-396462-5.00008-8).

Received 25.11.2020

Accepted 11.03.2021 